Research Article

Julia Marczewska* and Monika Jaworska

\title{
Statistical model used to assessment the sulphate resistance of mortars with fly ashes
}

https://doi.org/10.1515/eng-2019-0063

Received Feb 10, 2019; accepted Jun 05, 2019

\begin{abstract}
The use of low (LCFA) and high (HCFA) calcium fly ashes in the cement industry allows the implementation of European Union proposals on waste management and energy saving. However, the possibility of using HCFA is limited, because the properties of such waste from coalfired power plants must comply with national regulations. The paper shows the effect of partial replacement of Portland cement (OPC) by these fly ashes on the resistance of the sulphate attack of the mortars immersed in a 5\% solution of sodium sulphate. In order to determine the optimal amount of ash additive, a research plan was designed using statistical methods using the Gibbs triangle for mixtures. Samples of control mortars of OPC, binary mixtures of HCFA or LCFA and ternary mixtures of HCFA/LCFA were made. The composition of the blends was designed in accordance with the statistical plan of the experiment for mixtures. The testing program included linear strains, compressive strength and microstructure tests using SEM with EDXA and XRD analysis. The results of laboratory tests and statistical analyzes have shown that fly ash has a positive effect on the sulphate resistance of cementitious composites.
\end{abstract}

Keywords: high calcium fly ashes, mineral admixture, sulphate resistance

\section{Introduction}

The fly ashes from waste are widely used in construction as an active ingredient in the binder of cementitious composites. The fly ashes (FA) play a great importance in the modern concrete engineering and their use allow for economic and environmental benefits. High and low calcium

\footnotetext{
^Corresponding Author: Julia Marczewska: Department of Civil Engineering and Architecture, Kielce University of Technology, Poland; Email: jmarczewska@tu.kielce.pl Monika Jaworska: University of Technology and Humanities, Radom, Poland; Email: m.jaworska@uthrad.pl
}

fly ashes, as components of concrete modify the properties of both concrete mixture, fresh mortars as well as concrete and mortars. Properly used, they enable the production of high-quality and durable concrete in an ecological and economical way. The use of fly ashes for cement or concrete mixture allows to reduce the consumption of cement clinker to produce concrete, which results in a reduction of carbon dioxide emissions to the environment and a reduction in the consumption of fossil fuels and natural resources. Low calcium fly ashes are widely used as additives for cement and concrete. Around 675 million tons of fly ashes are produced every year around the world, of which only $16 \%$ [1, 2] are used. In Poland, about 20 million tons of fly ash is generated every year, half of which is from the combustion of lignite [3]. Due to the existing legal provisions [4-6] HCFA is used only in $20 \%$. The percentage of using the total Polish production of fly ash is $60 \%$ [7]. The composition of fly ash is unfortunately quite variable, because it depends on many factors [8,9]. Fly ash is used for masonry cements as a hydraulic binder in road engineering to stabilize the ground, substructure of low traffic and strengthening embankment slopes [10].

In the international literature [11-13] there have been found attempts to use HCFA for cementitious composites exposed to sulfate attack. These authors found that the additive was less effective than low calcium fly ash. However, the influence of various amounts of ash addition on sulfate resistance has not been investigated. The sulphate resistance of fly ash depends on the content of reactive crystalline phases and amorphous phases (calcium and aluminosilicate) $[14,15]$. The higher content of $\mathrm{CaO}$ and $\mathrm{SO}_{3}$ as well as the reduced amount of $\mathrm{SiO}_{2}$ and $\mathrm{Fe}_{2} \mathrm{O}_{3}$ in high calcium fly ash reduce the sulphate resistance of cementitious composites. Tishmack et al. [16] explains the low resistance of HCFA to sulfate attack smaller ratio of $\mathrm{SO}_{4} / \mathrm{Al}_{2} \mathrm{O}_{3}$, which promotes the formation of monosulphate. When the mortar is subjected to sulfate attack, the monosulphate is transformed into expansive ettringite. Attempts have been made to increase the HCFA sulfate resistance by adding gypsum to the mortar to optimize the $\mathrm{SO}_{4} / \mathrm{Al}_{2} \mathrm{O}_{3}$ ratio $[17,18]$ or silica fume $[17,19]$. Current research focuses largely on the durability of cemen-

¿ Open Access. ( 2019 J. Marczewska and M. Jaworska, published by De Gruyter. 
Table 1: Chemical composition of Portland cement clinker and fly ashes [\%].

\begin{tabular}{cccccccccc}
\hline & $\mathrm{SiO}_{\mathbf{2}}$ & $\mathrm{Al}_{\mathbf{2}} \mathbf{O}_{\mathbf{3}}$ & $\mathrm{Fe}_{\mathbf{2}} \mathbf{O}_{\mathbf{3}}$ & $\mathrm{CaO}$ & $\mathrm{CaO}_{(\text {free })}$ & $\mathbf{M g O}$ & $\mathbf{S O}_{\mathbf{3}}$ & $\mathrm{Cl}^{-}$ & $\mathbf{N a}_{\mathbf{2}} \mathbf{O}_{\mathbf{e q}}$ \\
\hline OPC & 19,5 & 6,0 & 3,1 & 62,1 & 1,75 & 1,7 & 2,6 & 0,03 & 0,8 \\
LCFA & 50,5 & 26,1 & 7,4 & 4,5 & 2,9 & 0,5 & 0,01 & & \\
HCFA & 45,2 & 20,8 & 4,6 & 20,6 & 1,5 & 3,0 & 0,014 & 0,23 & 0,19 \\
\hline
\end{tabular}

titious composites in the presence of sulphates [20, 21], because the sulphate resistance is a component of durability, which concerns the servicing of materials used in construction. Cement composites show deterioration after immersion in a sulphate solution due to expansion and cracking of the cement paste [22]. The loss of durability results from the formation of ettringite and gypsum due to the destruction of the C-S-H phase [23]. However, it has been proven that the use of fly ash causes a significant improvement in sulphate resistance [24]. Pozzolanic reaction reduces the amount of calcium hydroxide and the formation of lowcalcium phase C-S-H and C-S-A-H, which were the most sulfate resistant [25].

\subsection{Purpose and scope of the study}

The aim of the research included in this article was to investigate the effect of using HCFA for cementitious composites exposed to sulphate attack in relation to the effect of LCFA. It was also considered important to determine the optimal amount of HCFA and LCFA and their mixture, which can be introduced into the binder while maintaining high sulphate resistance of cementitious composites. Due to the variety of problems and research results, statistical methods of experiment planning and development of obtained research results were used. The statistical methods and models used are described in detail in the following chapters.

\subsection{Materials and methods used for testing}

The samples for testing were made of Portland cement CEM I 42.5 R (OPC). The chemical composition of Portland clinker given by the manufacturer is presented in the Table 1. The phase composition of Portland cement clinker: $54 \% \mathrm{C}_{3} \mathrm{~S}, 17 \% \mathrm{C}_{2} \mathrm{~S}, 11.5 \% \mathrm{C}_{3} \mathrm{~A}, 10.1 \% \mathrm{C}_{4} \mathrm{AF}$ The authors purposely chose cement with a high content of $\mathrm{C}_{3} \mathrm{~A}$ phase for research because of the faster time of progress of destruction of samples under the influence of sodium sulphate.

For the preparation of mortar used low calcium fly ash (LCFA) with a roasting loss of $2.5 \%$, specific surface area of $3233.00\left[\mathrm{~cm}^{2} / \mathrm{g}\right]$ on the Blaine's scale and high calcium fly

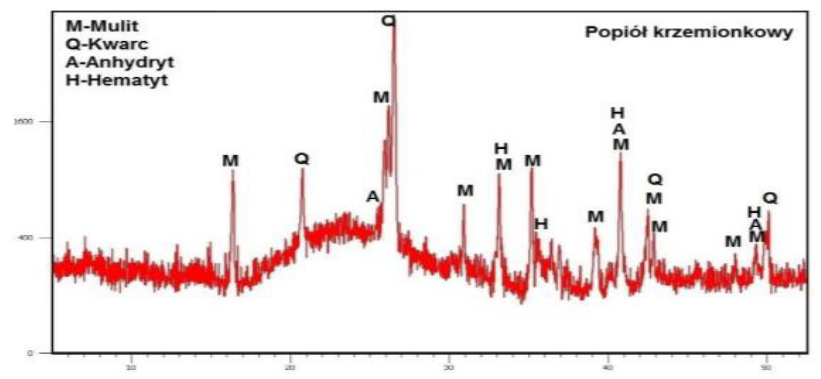

(a)

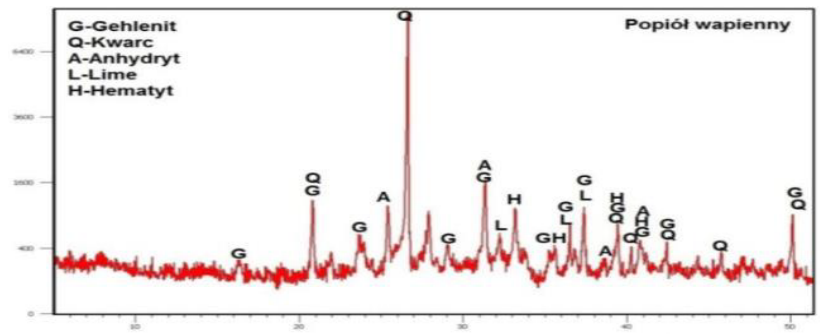

(b)

Figure 1: X-ray diffractogram of (a) low calcium fly ash, (b) high calcium fly ash.

ash (HCFA) with roasting losses of $2.7 \%$ and the specific surface of the ash equal to $2860.00\left[\mathrm{~cm}^{2} / \mathrm{g}\right]$ on the scale according to Blaine. Phase composition of low and high calcium fly ashes determined using XRD was presented on the diffraction patterns in Figure 1.

The fly ash used for the tests had a high content of reactive silica. The $\mathrm{SiO}_{2}$ content in both low and high calcium fly ashes was above $25 \%$, which influences their increased pozzolanic activity. In the case of HCFA, an increased content of $\mathrm{CaO}$ calcium above $15 \%$ was also observed, which may affect their greater hydraulic activity.

Seven series of mortars were performed in which the ratio of water to binder $(\mathrm{w} / \mathrm{s})$ was constant 0.6 . The proportions of components in the fresh mortars were as follows binder:sand:water $=1: 3: 0.6$. Natural quartz sand with a grain diameter of 0-2 mm was used for the mortar. For each series of mortars, 6 samples with dimensions of $4 \times 4 \times 16 \mathrm{~cm}$ were made, on which, according to PN-EN 196-1:2005 [26] a compressive strength test and 6 samples with dimensions of $2 \times 2 \times 16 \mathrm{~cm}$ were made, which after 28 days of curing un- 
Table 2: Blends prepared to evaluate sulphate resistance.

\begin{tabular}{cccc}
\hline Mix ID & PC (\%) & LCFA (\%) & HCFA (\%) \\
\hline M1 & 100 & - & - \\
M2-1 & 80 & 20 & - \\
M2-2 & 60 & 40 & - \\
M3-1 & 80 & - & 20 \\
M3-2 & 60 & - & 40 \\
M4-1 & 73,4 & 13,3 & 13,3 \\
M4-2 & 60 & 20 & 20 \\
\hline
\end{tabular}

der conditions air-dry were immersed in a 5\% solution of sodium sulphate as recommended by PN-B-19707 attachment C [27]. Table 2 shows the percentage of cement materials tested. The sulphate solution was replaced every 28 days.

The research program was designed based on a statistical experiment plan for ternary mixtures. The composition of the cement mortar binder was selected on the basis of the Gibbs triangle covering the area of up to $40 \%$ replacement of Portland cement by LCFA and HCFA or a mixture of them (Figure 2). The binder composition of the tested mortars was developed on the basis of the simplex plan of the experiment, which is used when testing the properties of a mixture depending on its composition. The rules for the selection of the composition of the mixture can be described using the variable vector:

$$
x=\left[x_{1}, x_{2}, \ldots, x_{S}\right]
$$

the variables are imposed by the following physical limitations:

1. the volume of the mixture is constant regardless of its composition:

$$
\sum x_{k}=\text { const }
$$

2. the content of each component in the mixture is nonzero:

$$
x_{k} \geq 0, k=1,2, \ldots, s .
$$

In the case of cement mortar containing three components such as: Portland cement, low and high calcium fly ashes, all possible compositions of the mixture lie in a plane delimited by a triangle (Figure 2).

\section{Test results and discussion}

Mortars made of Portland cement showed the least resistance to the influence of the sulphate solution (Figure 3).

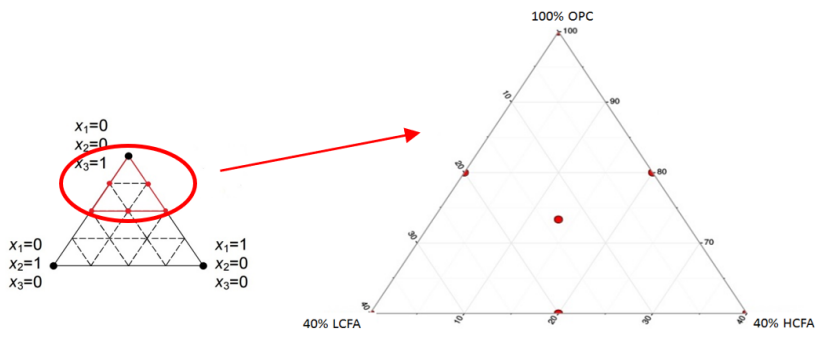

Figure 2: Plan of cement mortar mixtures.

Mortars in which 20\% cement was replaced by LCFA were damaged faster than mortars with $20 \%$ high calcium fly ash. It should also pay attention to the positive effect fly ashes mixtures for sulphate resistance of cement composites. Mortars with $40 \%$ content of fly ashes (low nad high calcium fly ashes as well as their mixture) showed practically no signs of damage, and the value of strain during the entire test period did not exceed 1\%.

The compressive strength was tested after 28 days of curing and after 170 and 360 days of immersion of the samples in the sodium sulphate solution and at the end of the test, respectively, when the samples showed signs of damage. The average strength changes on a percentage scale are shown in Figure 4. For each tested series, the value of the strength tested after 28 days of curing is $100 \%$.

The compressive strength of Portland cement mortars after 28 days of curing was higher than mortars with low and high calcium fly ashes. The lower 28-day mortar strength with a mineral admixture is associated with a relatively slow course of pozzolanic reaction in the initial hydration period. Despite the impact on the mortar of the aggressive solution for the first 170 days, the compressive strength of the samples in which $20 \%, 26.6 \%$ and $40 \%$ Portland cement were replaced respectively by low and high calcium fly ashes increased significantly. The mortars which 20\% cement OPC was replaced with HCFA after 170 days immersed in $5 \% \mathrm{Na}_{2} \mathrm{SO}_{4}$, compressive strength increased by about $20 \%$, while in the case of mortars with a $20 \%$ percentage of silica ash an increase of about $10 \%$ was observed. In mortars in which $40 \%$ of OPC was replaced by LCFA or / and HCFL, an increase in strength by $15 \%$ was observed. In the case of an increased amount of ash in the binder, i.e. $40 \%$, the decrease in strength after 360 days of residence in the solution was no more than $10 \%$ for each mortar in relation to strength after 170 days. 


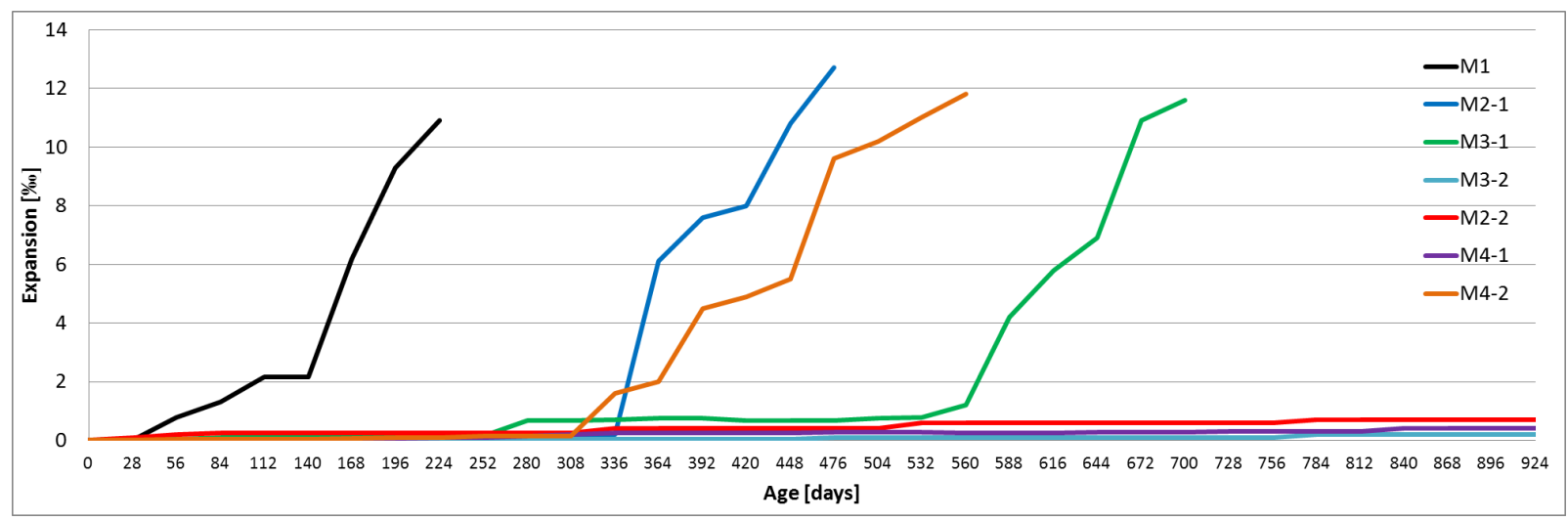

Figure 3: Expansion of mortars immersed in the $5 \% \mathrm{Na}_{2} \mathrm{SO}_{4}$ solution.

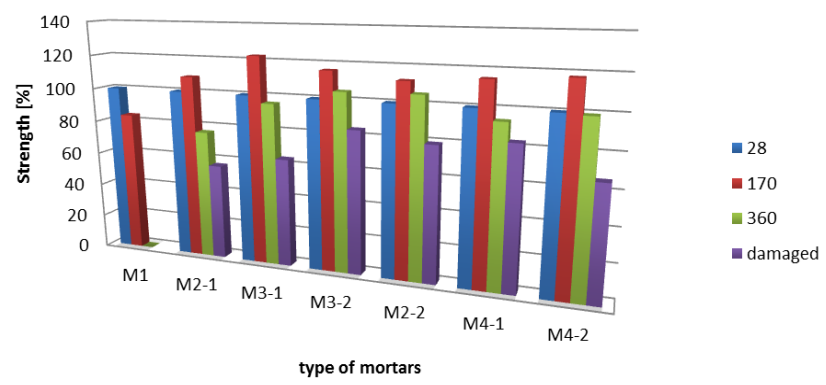

Figure 4: Strength for the mortars expressed as percentage at 28 days for each mortars series.

\subsection{Microstructure of mortars immersed in $5 \% \mathrm{Na}_{2} \mathrm{SO}_{4}$ solution}

In order to identify changes in the microstructure of cement mortars with the low and high calcium fly ashes or their mixtures X-ray diffraction was carried out at the moment of sample damage (Figure 5). The test time was different for each type of mortar. Samples made of OPC were taken for testing after 220 days in a $5 \% \mathrm{Na}_{2} \mathrm{SO}_{4}$ solution. In the case of specimens in which the binder had a mineral admixture, this time was extended accordingly.

The analysis of diffractograms has shown that the main products of sulphate attack are ettringite and gypsum. In the sample with low calcium fly ash, small reflections of portlandite were found. In mortars with $40 \%$ content of LCFA, the intensity of the gypsum phase reflections was less significant than in the case of mortars with $20 \%$ LCFA. This suggests slower reactions of sulphate ions with leaven in mortars with a larger amount of LCFA in which portlandite was also observed. Due to the fact that the test on mortars in which $40 \%$ Portland cement was replaced with fly ashes or their mixture was made while mortars with $20 \%$ ash content were damaged. The portlandite peaks and relatively low intensity of gypsum and ettrinigt peaks are clearly visible, which indicates a slight progress of corrosion.

The results of the test (Figure 6) carried out using the scanning electron microscope confirmed the presence of the same products that were identified by X-ray diffraction. In mortar samples, in which 20\% LCFA, the most frequently observed corrosion product was gypsum. Figure $6 \mathrm{a}$ and $6 \mathrm{~b}$ show the image and chemical analysis at the gypsum and ettringite points respectively in the samples tested. The common occurrence of sulfur, aluminum and calcium confirms that the corrosion products observed in this area are ettringite crystals.

\subsection{Statistical analysis of linear deformations and compressive strength of mortars}

Statistical analysis was performed based on the simplex plan of the experiment for ternary mixtures $[28,29]$. The calculations were performed in the R computing environment in version 3.3.1 (2016-06-21). The level of significance of all performed tests was assessed against the usual level of $\alpha=0.05$.

In order to determine the sulphate resistance of cement composites and the influence of fly ash included in the binder, an analysis of linear strains of samples subjected to sulfate attack and their compressive strength tested after 170 days in solution. The analyzes were carried out in accordance with the experimental design described on the second degree Simplex Lattice Design for three factors - i.e. the content of: cement (OPC), low calcium fly ash (LCFA) and high calcium fly ash (HCFL). The acceptance of the diagram (Figure 2) allowed to examine the effect of mortar composition on linear strain measure and strength taking into account possible synergistic effects (interac- 

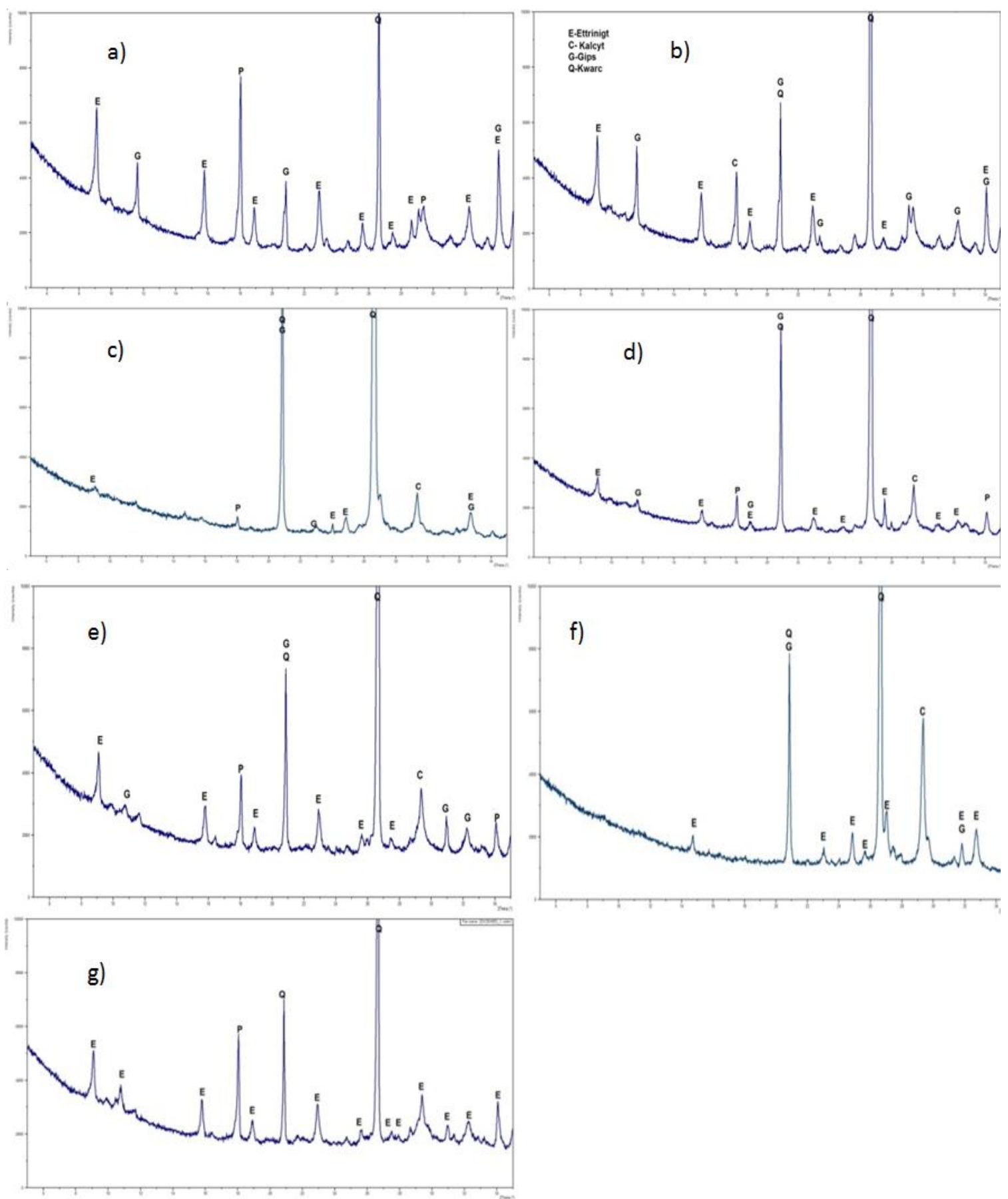

Figure 5: Diffraction pattern of mortars exposed to sodium sulphate (a) OPC mortar after 220 days in the solution, (b) M2-1 after 450 days, (c) M3-1 after 700 days, (d) M4-1 after 560 days, (e) M2-2 after 700 days, (f) M3-2 after 700 days, (g) M4-2 after 700 days in the solution. 


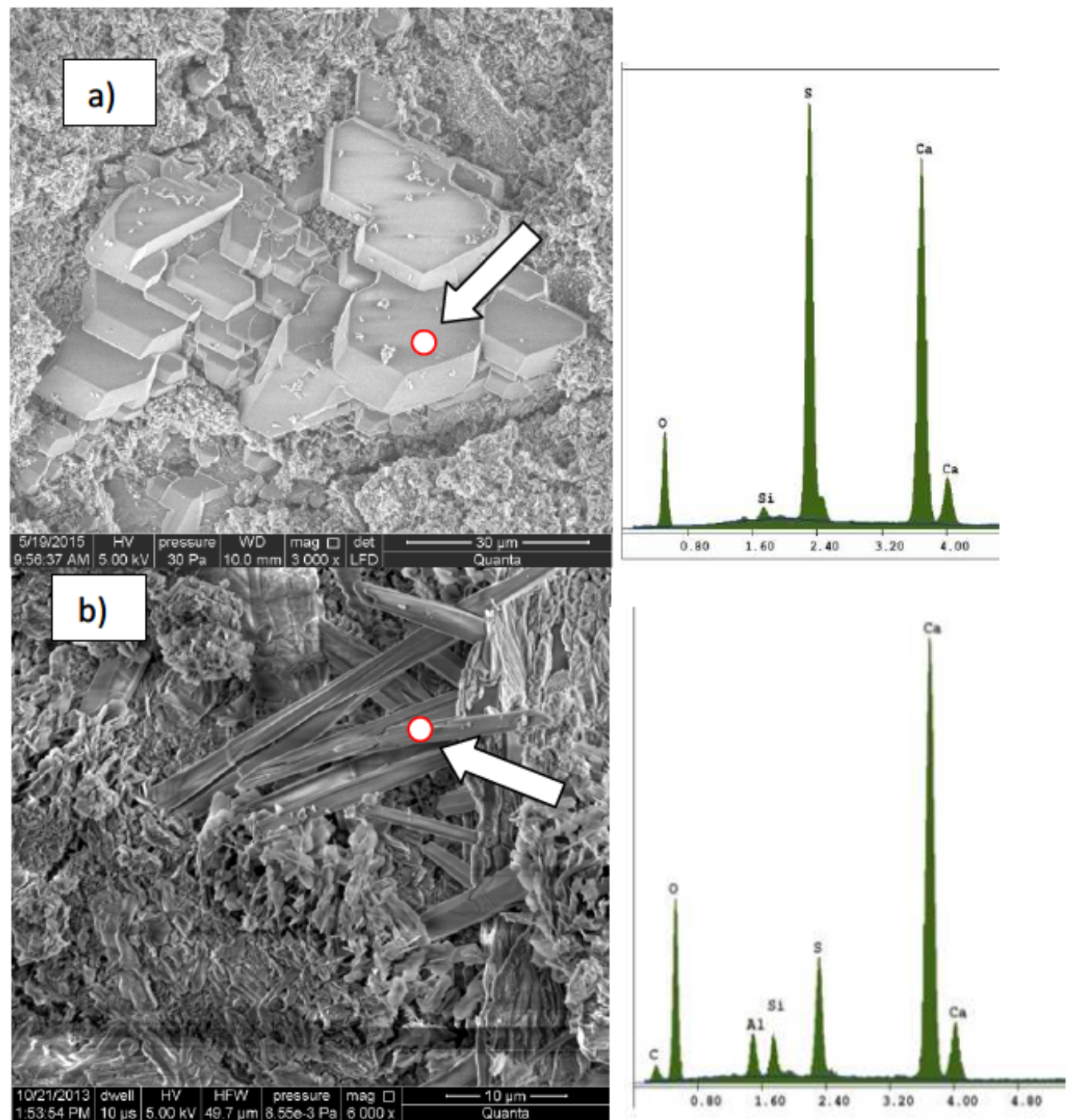

Figure 6: Gypsum (a) and ettringite (b) in mortars in which $20 \%$ cement was replaced by LCFA immersed with $5 \% \mathrm{Na}_{2} \mathrm{SO}_{4}$ with analysis of the chemical composition at point.

tions) between individual components of the cement mortar binder. The coefficients for individual effects in models based on the adopted experiment plan will mean a change in the level of the dependent variable in the case where the content of Portland cement in the binder ranges from $60 \%$ to $100 \%$. To calculate the level of variability of the variable depending on the mortar binder composition, the level of all three components (HCFA, LCFA, OPC) and all interactions between them was taken into account. The analysis of linear strain measure of samples subjected to the attack of sodium sulphate, showed a significant effect of the type and quantity of fly ashes used in the mortar. The model created for the sulfate attack explains $98.1 \%$ of the variance of linear strains of samples. Statistical analysis of the compressive strength results of samples immersed in a
$5 \% \mathrm{Na}_{2} \mathrm{SO}_{4}$ solution showed that the model explains only $67.7 \%$ of the variance of the compressive strength of samples.

Models of multiple linear regression allow to predict the level of linear strain (equation 4) and compressive strength (equation 5) of mortars immersed in $5 \% \mathrm{Na}_{2} \mathrm{SO}_{4}$ solution:

$$
\begin{aligned}
& Y_{L}=6.133 \star O P C+37.248 \text { * } L C F A \\
& +32.178 \text { * } H C F A-75.433 \text { * LCFA * OPC } \\
& -68.983{ }^{\star} H C F A \star O P C \\
& Y_{S}=38.511 \star O P C+116.841 \star H C F A \\
& -131.633{ }^{\star} H_{C F A}{ }^{\star} O P C-195.383{ }^{\star} L C F A \text { * } H C F A
\end{aligned}
$$


Table 3: Multiple linear regression model depending on the composition of cement bond binder after 170 days immersed in sulphate solution.

\begin{tabular}{ccccc}
\hline \multirow{2}{*}{ Effect } & \multicolumn{4}{c}{ Sulphate attack (linear strain measure) $(F(11.58)=271.00 ; p<0.001)$} \\
\cline { 2 - 5 } & $\mathrm{b}$ & $\mathrm{DG}$ & $\mathrm{GG}$ & $\mathrm{P}$ \\
\hline OPC & $\mathbf{6 . 1 1 3}$ & $\mathbf{5 . 7 5 2}$ & $\mathbf{6 . 4 7 4}$ & $<\mathbf{0 . 0 0 1}$ \\
LCFA & $\mathbf{3 7 . 2 4 8}$ & $\mathbf{3 0 . 9 0 1}$ & $\mathbf{4 3 . 5 9 5}$ & $<0.001$ \\
HCFA & $\mathbf{3 2 . 1 7 8}$ & $\mathbf{2 5 . 8 3 1}$ & $\mathbf{3 8 . 5 2 5}$ & $<\mathbf{0 . 0 0 1}$ \\
LCFA $^{\star}$ OPC & $-\mathbf{7 5 . 4 3 3}$ & $-\mathbf{8 5 . 7 9 4}$ & -65.072 & $<\mathbf{0 . 0 0 1}$ \\
HCFA $^{\star}$ OPC & -68.983 & -79.344 & $-\mathbf{5 8 . 6 2 2}$ & $<\mathbf{0 . 0 0 1}$ \\
LCFA*HCFA & 0.392 & -9.969 & 10.753 & 0.940 \\
\hline $\mathrm{R}^{2}$ & \multicolumn{3}{|c}{0.981} \\
\hline
\end{tabular}

Table 4: Relations between the mortar binder composition and strength - multiple linear regression models.

\begin{tabular}{ccccc}
\hline Effect & \multicolumn{4}{c}{ Sulphate attack (compressive strength) $(F(11.58)=11.10 ; p<0.001)$} \\
\cline { 2 - 5 } & $\mathrm{B}$ & $\mathrm{DG}$ & $\mathrm{GG}$ & $\mathrm{p}$ \\
\hline OPC & $\mathbf{3 8 . 5 1 1}$ & $\mathbf{3 4 . 8 4 5}$ & $\mathbf{4 2 . 1 7 7}$ & $<\mathbf{0 . 0 0 1}$ \\
LCFA & -20.959 & -85.480 & 43.561 & 0.518 \\
HCFA & $\mathbf{1 1 6 . 8 4 1}$ & $\mathbf{5 2 . 3 2 0}$ & $\mathbf{1 8 1 . 3 6 1}$ & $\mathbf{0 . 0 0 1}$ \\
LCFA*OPC & 84.867 & -20.457 & 190.192 & 0.112 \\
HCFA $^{\star}$ OPC & -131.633 & $-\mathbf{2 3 6 . 9 5 7}$ & $-\mathbf{2 6 . 3 0 8}$ & $\mathbf{0 . 0 1 5}$ \\
LCFA*HCFA & $-\mathbf{1 9 5 . 3 8 3}$ & $-\mathbf{3 0 0 . 7 0 7}$ & $-\mathbf{9 0 . 0 5 8}$ & $<\mathbf{0 . 0 0 1}$ \\
\hline $\mathbf{R}^{2}$ & \multicolumn{3}{|}{$\mathbf{0 . 6 7 7}$} \\
\hline
\end{tabular}

The analysis of the equations indicates that the use of fly ash has a significant impact on the final linear strain measure, indicate high coefficients for mortar made with the addition of LCFA and HGFA in comparison with mortars made of OPC. The linear regression model confirms the conclusions of the mean linear strain measure and average compressive strength of mortars immersed in sodium sulphate solution, that samples where a part of Portland cement was replaced by fly ashes or a mixture of them have a better sulphate resistance than samples made of Portland cement. Table 3 presents the model of multiple linear regression depending on the composition of the binder.

For the above model, a contour chart was created showing the predicted level of the dependent variable depending on the mortar binder composition (Figure 7). When analyzing contour diagrams, it is clearly visible that in the case of the sulphate solution impacting cement mortars, the smallest values of linear deformations are characteristic for the centroid region, i.e. for mortars in which a part of the cement was replaced by a mixture of fly ashes (26.6\% and 40\%) and around 40\% HCFA (i.e., mortars in which $40 \%$ Portland cement has been replaced with fly ash).

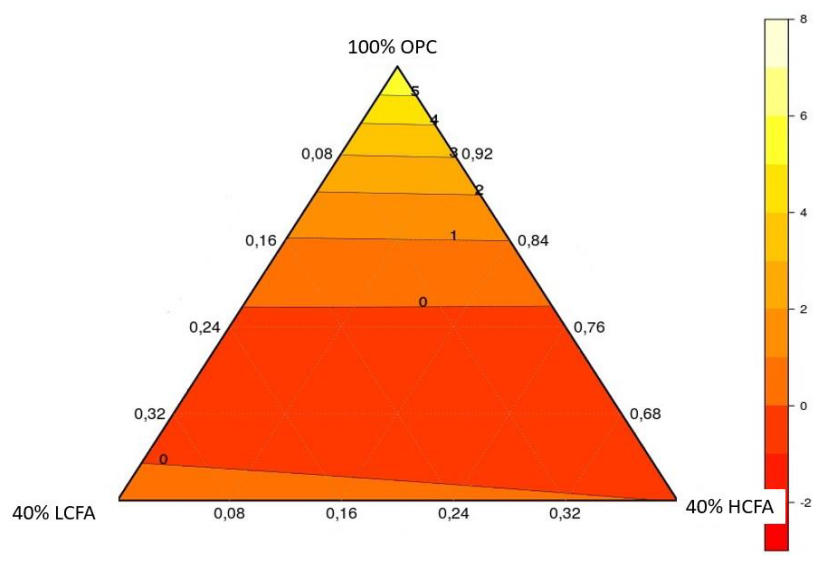

Figure 7: A contour chart for the model from Table 3 - linear strain measure of cement mortars immersed in $5 \%$ sulphate sodium solution.

Analysis of the above equations indicates that in the case of sulfate attack, the level of high calcium fly ashes have positive effect on strength weakens the level of low calcium fly ashes.

Additional insight into the nature of the mortar binder composition effects on the strength of mortars subjected to a sulphate attack give contour diagrams that show the pre- 


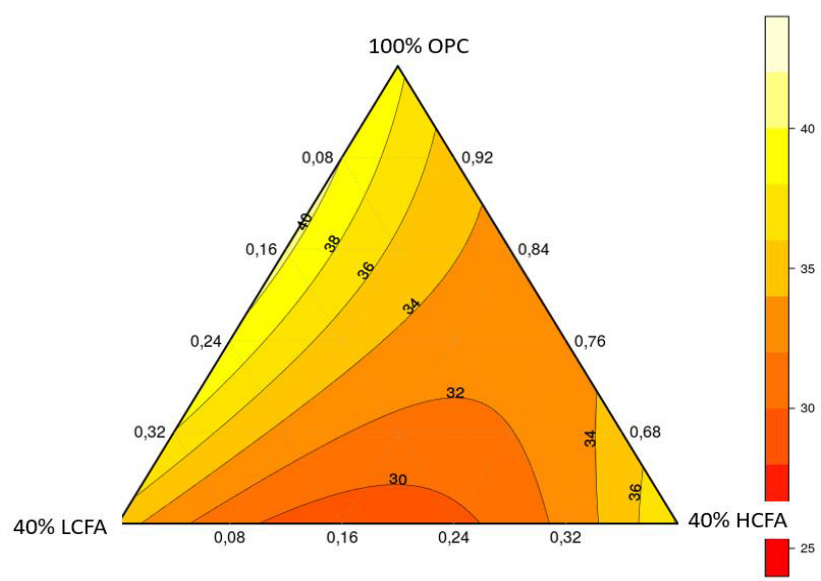

Figure 8: A contour chart for the model from Table 4 for the strength of the samples immersed in sodium sulphate.

dicted level of the dependent variable depending on the composition of the mortar (Figure 8).

Analyzing the contour diagrams, The smaller values of linear strain around the centroid, i.e. for mortars in which part of the cement was replaced by a mixture of fly ash (26.6\% and 40\%) and the region around 40\% HCFA were observed.

\section{Conclusions}

1. The admixture of fly ashes to cementitious composites significantly improves the resistance to sulphate attack. Mortar, in which $40 \%$ of Portland cement was replaced with LCFA, HCFA or their mixture, showed the best resistance to the solution of sodium sulphate.

2. Less-used HCFA compared to LCFA showed a similar effect on the sulphate resistance of mortars.

3. Bearing in mind the high variability of ash composition, it should be clearly indicated that the results obtained are not of a general nature. However, they contribute to understanding the possibilities of using waste material in cement composites with simultaneous improvement of mortar and concrete properties.

4. Properly selected plan of the experiment associated with statistical analysis allowed to determine the optimal amount of low or high calcium fly ashes or their mixtures, which can be introduced into the binder in order to improve the sulphate resistance of cement composites.
5. Statistical analysis is only the development of broad and long-term results of laboratory tests regarding mortar durability in a sulphate environment. Nevertheless, due to the very large number of test results and many variable factors, it seems to be necessary for proper assessment of sulphate resistance.

\section{References}

[1] Ahmaruzzaman M. (2010). A review on the utilization of fly ash, Prog. Energy Combust.Sci. 36, 327-363.

[2] International Energy Agency (IEA) (2017). Cement sustainability initiative, Technology Roadmap: Low-Carbon Transition in the Cement Industry, p. 66.

[3] Feuerborn H. (2009). Calcareous Ash in Europe - A Reflection on Technical and Legal Issues.

[4] Papayianni I., Tsimas S., Moutsatsou A. (2009). Standardization aspects concerning high calcium fly ashes, 3rd World Coal Ash, WOCA Conf.

[5] EN 450-1:2013, UNE- EN 450-1:2013 (2013). Fly Ash for Concrete Part 1: Definition, Specifications and Conformity Criteria.

[6] EN 197-1:2011(2011). Cement. Part 1: Composition, Specifications and Conformity Criteria for Common Cement.

[7] Uliasz-Bochenczyk A., Mokrzycki E. (2006). Fly ashes from polish power plants and combined heat and power plants and conditions of their application for carbon dioxide utilization, Chem. Eng. Res. Des. 84, 837-842.

[8] Dong Y., Jow J., Su J., Lai S. (2013). Fly ash separation technology and its potential applications; 2013 WOCA, Lexington, Kentucky, USA.

[9] Koukouzas N., Hämäläinen J., Papanikolaou D., Tourunen A., Jäntti T. (2007). Mineralogical and elemental composition of fly ash from pilot scale fluidised bed combustion of lignite, bituminous coal, wood chips and their blends, Fuel 86, 2186-2193.

[10] Giergiczny Z., Garbacik A., Baran T. (2010). Popioły lotne wapienne jako składnik pucolanowo-hydrauliczny cementów i aktywny dodatek do betonu, Monografia: Energia i środowisko w technologiach materiałów budowlanych, ceramicznych, szklarskich i ogniotrwałych, Praca zbiorowa, rozdział 14, 186-200.

[11] Tikalsky P.J., Carrasquillo R.L. (1992). Influence of fly ash on the sulphate resistance of concrete. ACI Struct J 89(1), 69-75.

[12] Shashiprakash S.G., Thomas M.D.A. (2001). Sulphate resistance of mortars containing high calcium fly ashes and combinations of highly reactive pozzolans and fly ash. In: Proceedings of the 7th CANMET/ACI international conference on fly ash, silica fume, slag, and natural pozzolan in concrete. Chennai, India 221-237.

[13] Shehata M.H., Thomas M.D.A., Bleszynski R.F. (1999). The effects of fly ash composition on the chemistry of pore solution in hydrated cement pastes. Cement Concr Res 29, 1915-20.

[14] Tikalsky P.J., Carrasquillo R.L. (1993). Fly ash evaluation and selection for use in sulphate-resistant concrete. ACI Mater J 90(6), 545-551.

[15] Kruse K.A. (2012). Characterization of high-calcium fly ash for evaluating the sulfate resistance of concrete, Masters Thesis, University of Texas, Austin 
[16] Tishmack J.K., Olek J., Diamond S. (1999). Characterization of high calcium fly ashes and their potential influence on ettringite formation in cementitous systems. Cement Concr Aggr 21(1), 8292.

[17] Freeman R.B., Carrasquillo R.L. (1995). Adjustments in gypsum content for production of sulphate-resistant blended cements containing high-calcium fly ash. ACI Mater J 92(4), 411-418.

[18] Shehata M.H., Adhikari G., Radomski S. (2008). Long-term durability of blended cement against sulphate attack. ACI Mater J 105(6), 594-602.

[19] Thomas M.D.A., Shehata M.H., Shashiprakash S.G., Hopkins D.S., Cail K. (1999). Use of ternary cementitious systems containing silica fume and fly ash in concrete. Cement Concr Res 29(8), 1207-1214.

[20] Chotetanorm C., Chindaprasirt P., Sata V., Rukzon S., Sathonsaowaphak A. (2013). High-calcium bottom ash geopolymer: sorptivity, pore size, and resistance to sodium sulfate attack, J. Mater. Civ. Eng. 25, 105-111.

[21] Sukmak P., De Silva P., Horpibulsuk S., Chindaprasirt P. (2015). Sulfate resistance of clay-portland cement and clay high-calcium fly ash geopolymer, J. Mater. Civ. Eng. 27(5), 1-11.

[22] Piasta W., Marczewska J., Jaworska M.. (2015). Durability of air entrained cement mortars under combined sulphate and freezethaw attack, Procedia Engineering 108, 55-62.
[23] Bakharev T. (2005). Durability of geopolymer materials in sodium and magnesium sulfate solutions, Cem. Concr. Res. 35, 12331246.

[24] Škvára F., Jílek T., Kopecky` L. (2005). Geopolymer materials based on fly ash, Ceram. Silik. 49(3), 195-204.

[25] Piasta W., tukawska M. (2016). The effect of sewage sludge ash on properties of cement composites, Procedia Engineering 161, 1018-1024.

[26] PN-EN 196-1:2005 (2005). Metody badania cementu - Część 1: Oznaczanie wytrzymałości.

[27] PN-B-19707:2013-10 (2013). Cement. Cement specjalny. Skład, wymagania i kryteria zgodności. Załącznik C: Oznaczanie odporności cementu na agresję siarczanową.

[28] Komsta Ł. (2004). Wprowadzenie do środowiska R, http://cran.rproject.org/doc/contrib/Komsta-Wprowadzenie.pdf

[29] Bondari K. (2005). Mixture Experiments and Their applications in Agricultural Research Experimental Statistics, Proceedings of the 30th Annual SAS Users Group International Conference (SUGI 30), Statistics and Data Analysis 209-230. 